\title{
Juridical Analysis on Responsibility of Notaries Against Counterfeiting Description Existence in An Authentic Agreement
}

\author{
Siska Dwi Astuti July ${ }^{1}$, Khusen Martono ${ }^{2}$ and Sri Endah Wahyuningsih ${ }^{3}$
}

Abstract. Article 1 Paragraph (1) of Act No. 2 of 2014 concerning Notary Office constitution that notaries are public officials, the authority to make the Act Authentic legitimate. Unfortunately in today's world that is filled by the desire of economic excess, not a few people on the mountain doing the wrong thing in order to enrich themselves, unfortunately including the notary who had exalted position in society as one of the authorities, instead of showing the action sublime them Authentic Act falsified. This study aims to clarify how the rule of law based on the positive law in Indonesia about such actions. Using normative juridical approach, and statutory approach, exploiting all the laws that have a correlation with the observed cases. To find practical application, researchers used the District Court of Semarang No. 676 / Pid.B /2017 PN.Smg The conclusion showed notary who forged authentic action violates the Notary Code and morally can not punish a criminal by Notary Code by the Board of Supervisors, but no conclusions about the case in the District Court ruling Semarang. While the notary may be punished criminally if proven wrong by article 264 of the Criminal Code no violation of law in Indonesia.

Keywords: Notary; Authentic Agreement; Suspect.

\section{Introduction}

The law has been in existence since the community itself surfaced, a concept of Emile Durkheim (1858-1917) after he was researching what solidarity spur on the body of society. Durkheim found that although solidarity can not be measured with certainty, he finds no empirical answer adhesive on the legal community. Of the theory, then he saw the link between certain types of law with the nature of solidarity in society. Both are 'legal action against' (repressive) and 'laws replace' (restitutive). Law cracking down is criminal law, while the law that replace work by providing a replacement, so that the state of society be recovered as a state before a criminal offense occurred, or what is now popularly known as 'restorative justice'. ${ }^{4}$

Unfortunately, the law is often broken. First by law enforcement that should perform any action under the law and thus prevent and / or punish any person who berbuatan unlawful, even breaking the law. Second, the law itself is worn where he could no longer adapt to the ever-changing times. The error is on the wrong people choose the people in charge of making laws, both at the local and central levels. The main fault of course addressed to the regulators themselves are often not visionary, but only a mere

\footnotetext{
1 Master of Notary's Student, Faculty of Law, Universitas Islam Sultan Agung email siysuka@gmail.com

2 Students of Master of Law, Faculty of Law, Universitas Islam Sultan Agung email nobitadi@gmail.com

${ }^{3}$ Lecturer of Faculty of Law UNISSULA

${ }^{4}$ Satjipto Rahardjo 2006 Ilmu Hukum PT.Citra Aditya Bakti Bandung p. 288-290.
} 
excited. Times have changed where human activities, especially those associated with the business / economy more quickly without being able to fully controlled by law.

The criminal offenses relating to the falsification of the authentic performed by a Notary is a reflection of the weakness of legal life in Indonesia as well as signs of the times in which the spirit of Pancasila begun to erode, which if unchecked would threaten the safety of the country, which according to Article 1 (1) of the Constitution of the Republic of Indonesia No. 2 of 2014 on the Amendment of Act No. 30 of 2004 concerning notary, notaries who is a public official with the authority of an authentic agreement along with some other authorities. According Urtrecht, the post is fiction. Legal actions carried out by proxy (vertegenwoordiging), who is an official (abtsdrager), which is thus very crucial role in carrying out the job. ${ }^{5}$ An official who should commit an act that provide security and be an example for and by the community where he served, instead perform an act that violates the law and the code of conduct of his profession.

In the authentic agreement forgery, it is often found that the notary did not work alone, but aided by those of its client in ways such as giving false particulars or create a fake signature, which will benefit them. Collusion between the parties who are clients and notaries aims not much to gain material is very highly regarded by the people of Indonesia at this time. Unfortunately collusion that occurs not in the context of good, but in the context of crime Pancasila which also violates the values of Islam which we are not allowed to cooperate for the crime, deceptive, and took advantage with malicious ways (breaking God's law).

But in the Notary Act (UUJN) is no mention of any sanctions convictions for offenses committed by a notary public if the actions contained elements of forgery either due to deliberate or negligence. However, after the sanction of the notary office code of professional conduct, actions could be withdrawn and qualified as a criminal offense. ${ }^{6}$ What is interesting is the opinion regarding the prohibition Habib Adjie police officer, prosecutor, judge, calling the alleged forged notary agreement without the consent of the Honorary Council / Board of Trustees, based on the content of article 66 UUJN. ${ }^{7}$ It impressed the stubbornness can become a notary by the general public who do not know the ordinance of the law enforcement code of ethics and to the notary who commit acts of counterfeiting agreement.

Based on the case is the case and thus the gravity of the decadent state of society, the scientific journal is written. The author intends to review how accountability notary agreements authentic agreement forgery when viewed from the code of conduct notary as moral guidelines that should underlie every step of the implementation of the notary duties, as well as enforcement mechanisms in the form of sanctions what would be obtained if he is found guilty; and how the criminal sanction in Indonesian positive law to be applied to the notary who convicted. By reviewing a case that has gained legal force remains the case Number 676 / Pid.B / 2016 / PN.Smg of 2017 in Semarang District Court,

\section{Research Methods}

\footnotetext{
${ }^{5}$ Ridwan HR 2006 Hukum Administrasi Negara RajaGrafindo Jakarta p. 76-77

${ }^{6} \mathrm{Habib}$ adjie 2008 Hukum Notaris Indonesia Refika Aditama Bandung p.25.

${ }^{7}$ Habib Adjie 2014 Hukum Notaris Indonesia (Tafsir Tematik Terhadap UU No. 30 Tahaun 2004 tentang Jabatan Notaris) PT. Refika Aditama Bandung p. 25.)
} 
The method used in this research is normative juridical approach. The study is a normative juridical approach to take place based on primary legal materials by means of studying the theories, concepts, despair legal principles and rules and regulations associated with this research. This approach is also known by the literature approach, by studying books, legislation and other documents related to this research. ${ }^{8}$

\section{Results And Discussion}

\subsection{Fraud Accountability Analysis of Notaries in Authentic Agreement Doing Liability Adulteration of the Authentic Based Notary Code}

According to Van Hamel, accountability is a normal state rather than human psychology by which man is capable of running three abilities, first, humans can understand the meaning as well as the consequences of his actions, the second, was able to realize that his actions were contrary to the rules in society, third, was able to determine the will do.

Furthermore, regarding the will to do that is associated with the error, there are three opinions. The first opinion, indeterminis, said human beings have a free will to take action where it is a volitional decision basis. If there is no free will, then there would be no mistakes, no reproach and no convictions. The second opinion, determinist, states that human beings are not memiliko free will. Willed decision was determined by the nature and motives entirely derived from stimuli within and outside the human self. But this does not create a criminal act free from liability. It will instead give rise to liability of any person for his actions, but the reactions to criminal oerbuatan iti form of action for public order. The third opinion, stating that the mistake had nothing to do with free will. Freedom of the will is a matter that is not related partnered with errors in criminal law. ${ }^{9}$

The term Notary Code, pursuant to Article 1 (2) Notary Code issued by the Indonesian Notary Association, is defined as the overall moral code prescribed by the Association of Indonesian Notary Association and / or prescribed by laws other which it applies and must be obeyed by all notaries. This means that all the rules that are in the Notary Code and UUJN a code of ethics are moral compass that should guide the notary running legal profession.

Article 3 (4) of the Code of Notaries that is approximately equal to Article 16 (1) points a UUJN memberikab command on the notary to always act in an honest, trustworthy, independent, impartial and responsible. If it later with sufficient evidence was found that he had been caught doing an act of fraud, it therefore means that the notary who had not been honest, impartial, and are not responsible, therefore violating the code of conduct.

In Article 6, paragraph (1) of the Code there is some kind of sanctions will be imposed to guilty notarized form of reprimand, warning; temporary suspension or dismissal from membership; Onzetting or permanent dismissal from membership; and final dismissal with no respect of membership. The imposition of sanctions by the next paragraph shall be adjusted by the quantity (the number of violations that have

\footnotetext{
${ }^{8}$ J. Supranto " Metode Penelitian Hukum dan Statistic " PT. Rineka Cipta Jakarta 2003 p. 2. ${ }^{9}$ Eddy OS Hiariej 2014 Prinsip-Prinsip Hukum Pidana Cahaya Atma Pustaka Yogyakarta p. 155156.
} 
occurred) and quality (the severity of the offense committed) violations of the member. Similarly, Article 16 (11) UUJN provide some sanctions for violators of the rules of Article 16 (1) points a through I that nerupakan code of conduct notary, namely a written warning, suspension, dismissal honorable and dishonorable discharge.

According to the Notary Code covering Notary Code issued by the Indonesian Notary Association and UUJN, the act of falsifying the agreement in violation of Article 3, paragraph (4) of the Code Notary INI and Article 16 (1) point a to I UUJN, such things can be sanctioned pursuant to Article 6, paragraph (1) and (2) of the Code INI and, if it is proven a person may be either liable to a reprimand, warning, suspension, onzetting, or a dishonorable discharge depending on how often and severe the offense. Also sanctioned beradasar Article 16 (11) UUJN pwringatan written form, suspension, dismissal honorable and dishonorable discharge.

\subsection{Code Enforcement Mechanism Against Counterfeit Performing the Authentic Agreement}

Based on the Code of Conduct INI three sections enforcement of codes of conduct, pemgawasan, inspection and sanctions, as well as the execution of sanctions.

On the first level of supervision Supervision is done by the Association of Regional Council of Notaries of Indonesia and the Regional Ethics; on appeal by the Regional Board Indonesian Notary Association together with Regional Ethics Board; finally at the end of a notary supervised by the Central Board of Notaries Association and the Honorary Board of the Center.

UUJN terms used in the Regional Supervisory Council term, Mahelis Regional Supervisor and Supervisor same Assembly artinyabdengan honorary board in terms of the Code comprising representatives from the government, notaries, and academics as stipulated in Article 67 paragraph (3) UUJN.

Regional Board, Regional Board and the Governing Council and its IT Center of Honor at the level of each of which acts as a watchdog.

According to Article 1 (5), (6) and (7) of the Code INI, Regional Executive Board of the Association is at the lowest level, namely Notary datau city districts, while the Regional Board is the Board of the association at the provincial level. Central Management Board of the Association is at the central / national, to represent and act on behalf of the association both outside and inside the court. Selanjutanya Article 8, which explains how the definition of the Honorary Board, namely fittings which is independent and independent duty to: 1). Fostering, mebimbing, monitor, fixing members and uphold the code of ethics, 2). Checking members and make decisions related to alleged violations of the code of ethics that is internal and not related to the community, 3).

Central Honorary Board is the Honorary Board at the national level, tasked among others to nurture, guide, monitor, fixing members, and uphold the code of ethics; examine and take decisions related to the nature of the code violations are final and final putsannya; give advice on the Supervisory Council for alleged violations of the code of conduct.

Inspection and sanctions on the first level are described in Article 9, 10, and 11 of the Code INI. At the first level, if any member of notaries allegedly violating the Code of Conduct, which it either comes from the knowledge of the Honorary Board of the Regional or report or the Regional Board also reports of other parties to the Regional Ethics Council, no later than seven working days of the Honorary Board Dae -rah shall 
immediately take actions such as the implementation of a Regional ethics Council session which has tyjuan discuss an alleged breach of the code of ethics allegedly committed unscrupulous notary. If there is a strong suspicion of a violation, then within seven (7) working days after the date of the hearing, the Regional Ethics Board must call a notary unexpected breakers to hear testimony and he was once given the opportunity to defend themselves.

Determining the decision made by the Regional Ethics Council in court or outside (another trial), no later than 15 (fifteen) days after the hearing to hear the statements notary. Regional Committee shall be consulted with regard to the sanctions of suspension and even dismissal.

Meanwhile at the appellate level is almost the same where the decision of dismissal sanction temporary and full dismissal can be submitted to the Council of Honor bandig Territory within 30 (thirty) days after the date of receipt of the SP sanctioning of the Honorary Council of Regions. After receiving the application, the notary called no later than seven (7) working days after receiving the request, returned to hear testimony and given the rights of the defense in the Regional Ethics Council session. The Council shall give judgment for 30 (thirty) days after the hearing.

Similarly, the resolution of an appeal, the sanction of dismissal while or dismissal of members of the association of the Honorary Board of the last inspection area can be filed in the Honorary Board of the Center, not later than 30 (thirty) days after the fall of the Honorary Council decision Territory. Honorary Council nottaris call center no later than 30 (thirty) days after samainya petition, heard testimony and given the opportunity to defend himself in the trial of the Honorary Board of the Center, where the decision should have been out before 30 (thirty) days have ended.

Decision Kehormata established by the Council of Regions, Regional Honor Council, and the Honorary Board of the Center, implemented by the Regional Board, which must be recorded in the book he said members of the association under Article 12.

Article 13 describes the unlucky dismissal while, when the notary proved bersalahh and has got a judicial action decision is legally binding, the Board shall be fired while the Pale of congress that followed membership association permanently fired.

Article 14 explains the imposition of sanctions, dismissal while and saki dishonorable discharge it must be announced by the Central Executive Council and a copy to the Regional Supervisor Menkumham.

In Semarang District Court decision has not been decided whether the punishment given to the defendant's conduct Sugiharto.

\subsection{Effects Analysis Conducting Notary agreement authentic agreement Counterfeiting}

\subsubsection{Responsibility Overview Someone Doing Agreements Criminal}

The theorem applies in criminal law formulated in the Germany, "Geen straf zonder Schuld" or "Keine Strafe ohne Schuld"; Latin adage "actus non facit reum nisi mens sit rea" or "actus reus mens rea". This principle, which means there is no criminal who applied unless someone was behaving unlawfully, making mistakes reprehensible. That principle is basic rather than the unwritten criminal liability could not be found in the legislation. Postulate that read, "punitur Nemo sine injuria, facto, seubdefalta", no one is punished unless he is guilty. 
Schuld zonder geen principle straf background classical flow of criminal law who see the action and effect perbuatab alone or known perpetrator tatstrafrecht. The law is always evolving and according to modern alirab actors become the center of gravity, known as taterstrafrecht that does not leave tatstrafrecht. Now neo classical threeoriented, action, result, and those who do, known as tat-taterstafrecht or daddaderstrafrecht. Criminal law runs a separate system which is basically 'between the characters act a criminal offense, and the character of those who do. George P. Fletcher states, people who commit criminal acts will not necessarily be subject to criminal, because it depends on whether the person can be held accountable demikoan criminal or not. But on the contrary ${ }^{10}$. The most important element in the accountability is a mistake. The elements of the error is, first, the ability to charge, second, the relationship between psychology and actions undertaken oelaku that gave rise to two forms namely deliberate errors and omissions, third, there is no reason for criminal eraser.

As explained by van Hamel that there are three measures of accountability that is able to understand inflicted, aware that his actions contrary to the laws of society, and is able to determine the will do, all three are cumulative, which means that if any one of these elements are not met, a person is not can be accounted for. ${ }^{11}$

\subsubsection{Notary Doing Criminalization of The Authentic Act of Forgery}

There are four important things according to Wesley Craig associated with Criminal Law in modern society, first, the criminalization is a necessity that is understandable and unavoidable, secondly, the implementation of criminal penalties that are a reflection rather than the criminal justice system continues to grow, the Federally not separated from the type and character criminal acts committed, the adage applies culpae fitting esto poena, punishment must be commensurate with the crime. Third, the implementation of the criminal must undergo a significant reform refers to a set of certain principles embraced by a nation, a fourth, a number of criminalization used must provide space or criteria for evaluating whether the criminal application already matches a purpose of punishment itself. ${ }^{12}$

In the criminal law applies the principle that people who commit criminal acts will not necessarily be subject to criminal, because it depends on whether the person can be held accountable demikoan criminal or not. On the contrary, if there are people who are subject to criminal sanctions, he never mind must have committed a crime that he can answer for.

Similarly, in the crime of forgery committed by a notary agreement. Accuracy in the examination of the evidence collected in the investigation frightening is required in order to know exactly which articles should be used to trap the accused of forgery, because in the field often appear several types of cases: first, when the notary and the parties did from the beginning of conspiring (notary knew that he would create a false agreement) in a agreement that will be detrimental to others and triggering a legal dispute, and the second where the notary did not know that the information given by the parties which trully false.

\footnotetext{
${ }_{11}^{10}$ (George P Fletcher 2000 Rethinking Criminal Law Oxford University Press Oxford p. 455)

${ }^{11}$ (Eddy OS Hiariej Ibid p. 163.)

12 (Eddy OS Hiariej Ibid p. 452.)
} 
When that happens is the first case, the notary may incur criminal agreement as forgery, namely the inclusion of such a thing was regulated in Article 55 paragraph (1) item 1 in conjunction with Article 264 paragraph (1) of the Criminal Code.

Article 55 paragraph (1) of the Criminal Code explains that someone who does, are told to do, or involved in the act would be convicted. Likewise, the notary can affected by Article 264 paragraph (1) the offense are basically on article 263 namely counterfeiting, with the core of the offense (delicts bestandellen): create a false letter or forgery, yabg can result in rights of debt relief or destined as evidence with respect to his a engagement rights, with this mean to wear or get someone else to wear the letter as if true and not false; criminal will rise to things that are described in points 1-5 of Article 264, including falsification of an authentic agreement.

Surely it must be with this understanding of criminal elements in the form of the first objective, agreements, acts of forgery, second, the object was a letter: it can rise to a right; give rise to an engagement; causing a discharge of indebtedness; used as evidence rather than something, the three can cause due to losses from the use of the letter; subjective and that is their intent to use or get someone else to wear as if it was true and not faked. There should be no mistake about it deliberate and accountability so that a notary can be imprisoned.

The second case in which a notary is not known the fake party, consider wearing article 266 paragraph (1) of the Criminal Code where people are threatened by this article described misalnay people who give false information to an officer catatanbsipil to put on the birth certificate, can also traders have made false agreement to a notary. ${ }^{13}$ Based on the article because the notary did not know nothing about untrue statements related parties simply because its position as oembuat agreement of the statement of the parties in this case Notaries can not be convicted.

In ruling that the authors analyzed Semarang District Court's Decision No. 676 / Pid.B / 2016 / PN.Smg of $2017^{14}$; verdict dated January 31, 2017 stated that Sugiharto bin Djasmin proven legally and convincingly guilty of committing the crime of falsification of the authentic act together and judges convict to imprisonment for eight (8) months with the criminal provisions need not be followed, unless prior probation 1 (one) year and 6 (six) months of the convicted person committed a crime, the decision has been appropriate and in accordance with the criminal law, namely Article 55 (1) and Article 264 paragraph (1)

\section{Closing}

\subsection{Conclution}

- According to the Notary Code (UUJN), the act of falsifying the agreement in violation of Article 3, paragraph (4) of the Code notary INI and Article 16 (1) point a to I UUJN, such things can be sanctioned under Article 6 paragraph (1) and (2) Code INI ethics and, if it is proven a person may be either liable to a reprimand, warning, suspension, onzetting, or a dishonorable discharge depending on how often and severe the offense. Also sanctioned beradasar Article 16 (11) UUJN written form, suspension, dismissal honorable and dishonorable discharge.

\footnotetext{
${ }^{13}$ Sughandi R. op.cit.

${ }^{14}$ Decision Directory MA, https://putusan.mahkamahagung.go.id/putusan/dce94dc480819a57f5a3c704670ec6eb
} 
- People who commit criminal acts will not necessarily be subject to criminal, because

- it depends on whether such a person can be held criminal liability or not. On the contrary, if there are people who are subject to criminal sanctions, he never mind must have committed a crime that he can answer for. When the notary is clearly evident conspiracy to make agreement plasu with the parties, he could be convicted with Article 55 paragraph (1) in conjunction with Article 264 paragraph (1) of the Criminal Code. On the other hand, if he does not know that the testimony of the parties are not in fact, he can not be punished.

\subsection{Suggestions}

- Supervision of notaries should be further enhanced. The role of the community becomes important to minimize violations of agreement. This can be done by the students or the public notary staff working at the notary's office to report the number of images and recording the evidence, to aimed at the Regional Supervisory Board as Trustees at the grassroots level. The Supervisory Board should also be independent in taking action against the notary. Do not like as MKD Parliament who actually help its members involved in a corruption scandal.

- Principle Restorrative Justice must be put forward and not just take action against perpetrators with penalties, but also help the aggrieved party to replace losses of money the convict for example, peace both parties must also be sought, so that the spirit of restorative justice even seem utopian to return things as they were prior acts criminal can be created.

\section{References}

[1] Satjipto Rahardjo 2006 Ilmu Hukum PT.Citra Aditya Bakti Bandung

[2] Ridwan HR 2006 Hukum Administrasi Negara RajaGrafindo Jakarta

[3] Habib adjie 2008 Hukum Notaris Indonesia Refika Aditama Bandung

[4] Habib Adjie 2014 Hukum Notaris Indonesia (Tafsir Tematik Terhadap UU No. 30 Tahun 2004 tentang Jabatan Notaris) PT. Refika Aditama Bandung

[5] J. Supranto " Metode Penelitian Hukum dan Statistic" PT. Rineka Cipta Jakarta 2003.

[6] Eddy OS Hiariej 2014 Prinsip-Prinsip Hukum Pidana Cahaya Atma Pustaka Yogyakarta.

[7] George P Fletcher 2000 Rethinking Criminal Law Oxford University Press Oxford

[8] MA,https://putusan.mahkamahagung.go.id/putusan/dce94dc480819a57f5a3c704670ec6eb 